\title{
Medication adherence and determinants of non-adherence among south Indian diabetes patients
}

\author{
Ravi Kumar Medi ${ }^{1}$, Uday Venkat Mateti ${ }^{1,2}$, Krishna Reddy Kanduri ${ }^{3}$, Shiv Sagar Konda ${ }^{2}$ \\ ${ }^{1}$ Department of Pharmacy Practice and Pharm D, St. Peter's Institute of Pharmaceutical Sciences, Kakatiya University, Warangal, Andhra \\ Pradesh, ${ }^{2}$ Manipal College of Pharmaceutical Sciences, Manipal University, Manipal, Karnataka, ${ }^{3}$ Department of General Medicine, Rohini Super \\ Specialty Hospital, Warangal, Andhra Pradesh, India
}

\section{A B S T R A C T}

Objectives: The objective of the study is to determine the adherence and determinants of non-adherence among diabetes patients. Materials and Methods: A cross-sectional observation study was conducted for a period of six months in both inpatients and outpatients of diabetic clinic at a super speciality hospital. The structured medication adherence questionnaire (MAQ) was administered to the eligible diabetic patients to assess the adherence rate and determinants of non-adherence. Results: During the study period, a total of 140 patients were enrolled. Out of I 40 patients, most of them were females $(n=79,56.57 \%)$, than males $(n=61,43.57 \%)$. Among them $(n=49,35 \%)$ patients were in the age group greater than or equal to $6 \mathrm{I}$ years followed by $(n=42$, $30 \%$ ) patients between $5 \mathrm{I}-60$ years and others. The overall medication adherence rate was found to be $47.85 \%$. The main factors for non-adherence were lack of finance $(n=43,55.84 \%)$, forgetfulness $(n=36,46.75 \%)$, being busy $(n=34,44.15 \%)$, medicines inaccessibility $(n=15,19.48 \%)$ and others. Conclusion: The overall medication adherence rate was found to be unsatisfactory. The main challenging factors affecting medication adherence were lack of finance, forgetfulness, being busy, medicines inaccessibility and side effects of drugs.

Key words: Adherence, determinants, diabetes, India

\section{INTRODUCTION}

Medication adherence is a leading issue and a huge burden in our current healthcare system. In the limited resource-country like India, the preponderance of economic instability, low literacy level, and restricted access to healthcare facilities might have led to the increase incidence of medication non-adherence. Medication compliance has been defined by the International Society for Pharmacoeconomics and Outcomes Research as the "extent to which a patient acts in accordance with

\begin{tabular}{|l|l|}
\hline \multicolumn{2}{|c|}{ Access this article online } \\
\hline Quick Response Code: & Website: \\
\hline & www.joshd.net \\
\hline & \\
\hline & \\
\hline
\end{tabular}

the prescribed interval and dose of a dosing regimen". [1] Diabetes related morbidity and mortality are becoming more prevalent in India. ${ }^{[2]}$ Medication adherence in diabetic patients significantly varies from $36 \%$ to $93 \% .{ }^{[3]}$ Treatment effectiveness decreases with non-adherence to prescribed medications thereby, increasing healthcare costs of diabetes..$^{[4-8]}$ Globally, full compliance to the treatment for chronic illness is $50 \%$, and this is far less in case of developing countries like India. ${ }^{[9]}$ With every $10 \%$ increase in medication adherence there is a decrease in $\mathrm{HbA} 1 \mathrm{c}$ by $0.16 \% .{ }^{[5]}$ Elderly patients are more likely to be non-compliant and so educational programs on diabetes self management should be conducted for which there is a growing need for more research in this area. ${ }^{[7]}$ To the best of our knowledge, there is a scarcity of literature appraising medication adherence and determinants of non-adherence among type 2 diabetes patients in India. Thus, the need of this study is to assess medication adherence of diabetes patients in south Indian hospital.

Corresponding Author: Dr. Uday Venkat Mateti, Manipal College of Pharmaceutical Sciences, Manipal University, Manipal, Karnataka, India. E-mail: udayvenkatmateti@gmail.com 


\section{MATERIALS AND MethOdS}

A cross-sectional observation study was conducted including both inpatients and outpatients for a period of 6 months (February-July 2012), in diabetic clinic at a superspeciality hospital. Diabetic patients of both sex and age above 18 years were included in the study. The study was approved by the hospital committee prior to the study initiation. The structured medication adherence questionnaires (MAQ) was framed and validated by committee of experts of healthcare providers such as two physicians who are experts in the field of diabetology and three pharmacists who are experienced in diabetes pharmacotherapy. The structured MAQ was designed in English and translated into Telugu language, and was administered to the patients. Patients were asked to answer the questionnaire in point of view of their previous medication usage pattern. The MAQ mainly consists of socio-demographics such as age, gender, height, weight, education, occupation, smoking habit, medical and social history, determinants of non-adherence with drug therapy like pattern of drug use, reason for missed dose, factors for non- adherence, type of daily medication remainder, knowledge of complications due to poor glycemic control, regular home blood glucose measurement, knowledge of optimal blood glucose target, and identification of medications. The collected data was entered into
Microsoft@ Excel to a Microsoft Excel worksheet to obtain the result, which was expressed as number and percentage.

\section{RESULTS}

Sociodemographic details of the patients

During the study period, a total of 140 patients were enrolled. Out of 140 patients, most of them were females $(n=79,56.57 \%)$, than males $(n=61,43.57 \%)$. Among them $(n=49,35 \%)$ patients were in the age group greater than or equal to 61 years, followed by $(n=42,30 \%)$ patients between $51-60$ years and others. In the present study, $(n=77,55 \%)$ patients were illiterates, duration of diabetic history was in the range of one to five years $(n=69,49.28 \%)$, and hypertension $(n=100,71.42 \%)$ were the most common co-morbid conditions. The detailed summary of sociodemographic details of the patients presented in Table 1.

Medication adherence rate and determinants of non-adherence

In the present study of 140 patients, $69.28 \%$ are aware of optimal blood glucose levels, but only $7 \%$ of patients regularly check their blood sugars at home. When questioned regarding medication identification, 47.14\% of patients identify their medications with brand or generic names, $38.57 \%$ identify with color, shape and size, while $14.28 \%$ with medication wrapper. It was found

\begin{tabular}{|c|c|c|c|c|c|c|c|}
\hline \multirow{2}{*}{$\begin{array}{l}\text { Demographic details } \\
\text { Age (years) }\end{array}$} & \multicolumn{3}{|c|}{ No. patients (\%) } & \multirow{2}{*}{$\begin{array}{l}\text { Demographic } \\
\text { details } \\
\text { Duration of } \\
\text { Diabetes }\end{array}$} & \multicolumn{3}{|c|}{ No. patients (\%) } \\
\hline & $\begin{array}{c}\text { Inpatients } \\
(n=43)\end{array}$ & $\begin{array}{l}\text { Out patients } \\
(n=97)\end{array}$ & $\begin{array}{l}\text { Overall } \\
(n=140)\end{array}$ & & $\begin{array}{l}\text { Inpatients } \\
(n=43)\end{array}$ & $\begin{array}{l}\text { Out patients } \\
\qquad(n=97)\end{array}$ & $\begin{array}{l}\text { Overall } \\
(n=140)\end{array}$ \\
\hline $18-30$ & $2(4.65)$ & - & $2(1.42)$ & Less than 1 year & - & - & - \\
\hline $31-40$ & $2(4.65)$ & $05(5.15)$ & $7(5)$ & $1-5$ years & $25(58.13)$ & $44(45.36)$ & $69(49.28)$ \\
\hline $41-50$ & 9 (20.93) & 31 (31.95) & $40(28.57)$ & $5-10$ years & $10(23.25)$ & $40(41.23)$ & $50(35.71)$ \\
\hline $51-60$ & $14(32.55)$ & $28(28.86)$ & $42(30)$ & More than 10 years & $08(18.60)$ & $13(13.40)$ & $21(15)$ \\
\hline$\geq 61$ & $16(37.02)$ & $33(34.02)$ & $49(35)$ & Co-morbid condition & & & \\
\hline Gender & & & & Hypertension & $28(65.11)$ & $72(74.22)$ & $100(71.42)$ \\
\hline Males & $28(65.11)$ & $33(34.02)$ & $61(43.57)$ & Ischemic stroke & $02(4.65)$ & $30(30.92)$ & $32(23.85)$ \\
\hline Females & $15(34.88)$ & $64(65.97)$ & $79(56.42)$ & Dyslipidemia & 09 (20.93) & 35 (36.08) & $44(31.42)$ \\
\hline Educational status & & & & $\begin{array}{l}\text { Ischemic heart } \\
\text { disease }\end{array}$ & $01(2.32)$ & $01(1.03)$ & $2(1.42)$ \\
\hline Illiterate & $16(37.20)$ & $61(62.88)$ & $77(55)$ & Chronic renal failure & $01(2.32)$ & - & $1(0.71)$ \\
\hline High school & $19(44.18)$ & $27(27.83)$ & $46(32.08)$ & Retinopathy & $10(23.25)$ & $3(3.09)$ & $13(9.28)$ \\
\hline Board of Intermediate & $03(6.97)$ & $07(7.21)$ & $10(7.14)$ & Urinary tract infection & - & $11(11.34)$ & $11(7.85)$ \\
\hline U.G \& P.G & $05(11.62)$ & $02(2.06)$ & $7(5)$ & Monthly income (INR) & & & \\
\hline Body mass index (kg/m²) & & & & $2000-5000$ & 27 (62.79) & $60(61.86)$ & $87(62.14)$ \\
\hline Under weight $(<18.50)$ & $02(4.65)$ & $09(9.27)$ & $11(7.85)$ & $5001-7500$ & $06(13.95)$ & $14(14.43)$ & $20(14.28)$ \\
\hline Normal weight $(18.51-24.99)$ & $30(69.76)$ & $58(59.79)$ & $88(62.85)$ & $>7500$ & $10(23.25)$ & $23(23.71)$ & $33(23.57)$ \\
\hline Over weight ( $25.00-29.99)$ & 09 (20.93) & $28(28.86)$ & $37(26.42)$ & Community & & & \\
\hline Obese $(\geq 30)$ & $02(4.65)$ & $02(2.06)$ & $4(2.85)$ & Rural & $29(67.44)$ & $59(60.82)$ & $88(62.85)$ \\
\hline Social habits & & & & Urban & $14(32.55)$ & $38(39.17)$ & $52(37.14)$ \\
\hline Smokers & $10(23.25)$ & $14(14.43)$ & $24(17.14)$ & & & & \\
\hline Alcoholics & $05(11.62)$ & $07(7.21)$ & $12(8.5)$ & & & & \\
\hline Both smokers and Alcoholics & 09 (20.93) & $50(51.54)$ & $59(42.14)$ & & & & \\
\hline
\end{tabular}


that $47.85 \%$ patients never missed doses; $28.57 \%$ patients missed daily dose sometimes (less than 5 doses per week), whereas $23.57 \%$ of patients frequently missed daily doses (more than 5 doses per week). It was found that $47.85 \%$ patients were adherent to medications. The main factors for non-adherence were lack of finance $(n=43,55.84 \%)$, forgetfulness ( $n=36,46.75 \%)$, being busy $(n=34,44.15 \%)$, medicines inaccessibility $(n=15,19.48 \%)$ and others. The detailed summary of determinants of non-adherence is presented in Table 2.

\section{DISCUSSION}

In the present study, the overall medication adherence rate was found to be $47.85 \%$, which was less than the study conducted by Wabe et al., and Grant et al. ${ }^{[10,11]}$ About $30.71 \%$ patients have no knowledge about optimal blood glucose levels; 95\% patients were not aware of Self Monitoring of Blood Glucose (SMBG) at home. Thirtyfive percent of patients were from age group greater than or equal to 61 years; $46.75 \%$ patients had difficulty in remembering time of dosing, and this could be due to forgetfulness, which is most common in this age group. As most of the patients belong to a rural community $(62.85 \%)$, the percentage of illiterate patients were found to be more $(55 \%)$, and $33 \%$ of patients had a problem in accessing medicines. The average cost per diabetic patient with and without complications in a south Indian hospital during their hospital stay is 16,956 INR (314.15 USD) and 1622 INR (29.91USD), respectively. ${ }^{[2]}$ The lack of finance, which is evident from their monthly income falling between 2000 to 5000 INR, could be the reason for non-adherence to medications in $55.84 \%$ patients, whereas the results of a study conducted by Santhosh et al. shows that almost same percent of patients are in the same age group and percentage of illiterate patients were low. ${ }^{[12]}$ Hypertension (71.42\%) and dyslipidemia (31.42\%) were the co-morbidities frequently present among our study population, while hypertension and obesity were the most frequent co-morbidities in studies done by Wabe et al. and Isomaa et al. ${ }^{[10,13]}$ Challenging factors like lack of finance (55.84\%), forgetfulness (46.75\%), being busy (44.15\%), inaccessibility of medicines (19.48\%), attribute to poor adherence to anti-diabetics, whereas the results of a similar kind of study conducted in Ethiopia shows that study forgetfulness $(50.2 \%)$, lack of finance (37.1\%), side-effect of drug (29.2\%), inaccessibility of medicines $(5.6 \%)$ are influencing the medication adherence. ${ }^{[10]}$ About $52.14 \%$ of patients use Daily Medication Reminder (DMR), to remind them to take their prescribed medication; among them most of the patients $(58.90 \%)$ use it as morning and meal time doses. These likely increase the chance

\begin{tabular}{|c|c|c|c|}
\hline Questions & $\begin{array}{l}\text { Inpatients } \\
\qquad N(\%)\end{array}$ & $\begin{array}{c}\text { Out patients } \\
N(\%)\end{array}$ & $\begin{array}{c}\text { Overall } \\
n=140 N(\%)\end{array}$ \\
\hline $\begin{array}{l}\text { Knowledge of optimal } \\
\text { blood glucose target }\end{array}$ & \multicolumn{2}{|c|}{$[\mathrm{IP} n=43 ; \mathrm{OP} n=97]$} & $n=140$ \\
\hline Yes & 31 (72.09) & $66(68.04)$ & $97(69.28)$ \\
\hline No & $12(27.90)$ & 31 (31.95) & $43(30.71)$ \\
\hline $\begin{array}{l}\text { Regular home blood } \\
\text { glucose measurement }\end{array}$ & \multicolumn{2}{|c|}{$[\mathrm{IP} n=43 ; \mathrm{OP} n=97]$} & $n=140$ \\
\hline Yes & $6(13.95)$ & $1(1.03)$ & $7(5)$ \\
\hline No & $37(86.06)$ & $96(98.96)$ & $133(95)$ \\
\hline $\begin{array}{l}\text { Knowledge of } \\
\text { complications due to poor } \\
\text { glycemic control }\end{array}$ & \multicolumn{2}{|c|}{$[\mathrm{IP} n=43 ; \mathrm{OP} n=97]$} & $n=140$ \\
\hline Poor visibility & $37(86.04)$ & $70(72.16)$ & $107(76.42)$ \\
\hline Foot ulcer & $1(2.32)$ & $2(2.06)$ & $3(2.14)$ \\
\hline Others & $5(11.62)$ & $25(25.77)$ & $30(21.42)$ \\
\hline $\begin{array}{l}\text { How will you identify your } \\
\text { medicines? }\end{array}$ & \multicolumn{2}{|c|}{$[\mathrm{IP} n=43 ; \mathrm{OP} n=97]$} & $n=140$ \\
\hline $\begin{array}{l}\text { By brand name/drug } \\
\text { name }\end{array}$ & $23(53.48)$ & $43(44.32)$ & $66(47.14)$ \\
\hline By medication wrapper & $6(13.95)$ & $14(14.43)$ & $20(14.28)$ \\
\hline $\begin{array}{l}\text { By colour, shape and } \\
\text { size }\end{array}$ & $14(32.55)$ & $40(41.23)$ & $54(38.57)$ \\
\hline Cannot identify & - & - & - \\
\hline Pattern of drug use & \multicolumn{2}{|c|}{ [IP $n=43 ;$ OP $n=97]$} & $n=140$ \\
\hline Never missed & $8(18.6)$ & $59(60.82)$ & $67(47.85)$ \\
\hline $\begin{array}{l}\text { Missed daily dose } \\
\text { sometimes }\end{array}$ & $12(27.9)$ & $28(28.86)$ & $40(28.57)$ \\
\hline $\begin{array}{l}\text { Missed daily dose } \\
\text { frequently }\end{array}$ & $23(53.4)$ & $10(10.30)$ & $33(23.57)$ \\
\hline Reason for missing dose & \multicolumn{2}{|c|}{$[\mathrm{IP} n=35 ; \mathrm{OP} n=38]$} & $n=73$ \\
\hline Lack of finance & $19(54.28)$ & $24(57.14)$ & $43(55.84)$ \\
\hline Forgetfulness & $21(60)$ & $15(35.71)$ & $36(46.75)$ \\
\hline Being busy & $11(31.42)$ & $23(54.76)$ & $34(44.15)$ \\
\hline Medicines inaccessibility & $7(20)$ & $8(19.04)$ & $15(19.48)$ \\
\hline Side effect of drug & $6(17.14)$ & $5(11.90)$ & $11(14.28)$ \\
\hline Multiple drug therapy & $3(8.57)$ & $5(11.90)$ & $8(10.39)$ \\
\hline Decision to omit & $2(5.71)$ & $02(4.76)$ & $4(5.19)$ \\
\hline Others & $1(2.85)$ & $02(4.76)$ & $3(3.8)$ \\
\hline $\begin{array}{l}\text { Type of daily medication } \\
\text { reminder }\end{array}$ & \multicolumn{2}{|c|}{$[\mathrm{IP} n=26, \mathrm{OP} n=47]$} & $n=73$ \\
\hline Morning time & - & $2(4.25)$ & $2(2.74)$ \\
\hline Meal time & $3(11.53)$ & $3(6.38)$ & $6(8.21)$ \\
\hline Bed time & $3(11.53)$ & $5(10.63)$ & $8(10.95)$ \\
\hline $\begin{array}{l}\text { Both moring and meal } \\
\text { Time }\end{array}$ & $15(57.69)$ & $28(59.57)$ & $43(58.90)$ \\
\hline Three times a day & $5(19.23)$ & 9 (19.14) & $14(19.17)$ \\
\hline $\begin{array}{l}\text { Special instructions from } \\
\text { doctor taking medications }\end{array}$ & \multicolumn{2}{|c|}{$[\mathrm{IP} n=43 ; \mathrm{OP} n=97]$} & $n=140$ \\
\hline Yes & $38(88.37)$ & $67(69.07)$ & $105(75)$ \\
\hline No & $5(11.62)$ & 30 (30.92) & $35(25)$ \\
\hline $\begin{array}{l}\text { If Yes, then how often do } \\
\text { you follow them? }\end{array}$ & \multicolumn{2}{|c|}{$[\mathrm{IP} n=38 ; \mathrm{OP} n=67]$} & $n=105$ \\
\hline Some times & $25(65.78)$ & $36(53.73)$ & $61(58.08)$ \\
\hline Most of the times & $8(21.05)$ & $21(31.34)$ & $29(27.61)$ \\
\hline All the times & $5(13.15)$ & $10(14.92)$ & $15(14.28)$ \\
\hline
\end{tabular}

of achieving high patient adherence with prescribed medications and subsequent optimal glycemic control.

As evident from various studies, medication adherence can be improved by dosage simplification, educating the patients on aspects of drugs, disease state and lifestyle modifications, using reminder systems like weekly pill boxes and packaged 
calendars, telephonic and pager reminder. ${ }^{[14-17]}$ Newly developed smart phone applications can improve medication adherence, but their reliability is not yet studied. ${ }^{[18]}$

\section{CONCLUSION}

This study is helpful in understanding non-adherence in diabetic patients in South Indian Hospital. Most of the patients from rural areas are not properly educated about diabetes and its debilitating long-term complications; due to which morbidity and mortality are increased as seen from other studies. The overall medication adherence rate was unsatisfactory. Most of the patients in our study do not monitor sugars at home. Diabetic patients must be aware of SMBG, as it has significant effect in achieving glycemic targets. Medical community needs health professionals to educate the patients about their disease states and compliance to prescribed medications.

\section{REFERENCES}

1. Cramer JA, Roy A, Burrell A, Fairchild CJ, Fuldeore MJ, Ollendorf DA, et al. Medication compliance and persistence: Terminology and definitions. Value Health 2008;11:44-7.

2. Akari S, Mateti UV, Kunduru BR. Health-care cost of diabetes in South India: A cost of illness study. J Res Pharm Pract 2013;2:114-7.

3. Cramer JA. A systematic review of adherence with medications for diabetes. Diabetes Care 2004;27:1218-24.

4. Lawrence D, Ragucci KR, Long LB, Parris BS, Helfer LA. Relationship of oral antihyperglycemic (sulfonylurea or metformin) medication adherence and hemoglobin A1C goal attainment for $\mathrm{HMO}$ patients enrolled in a diabetes disease management program. J Manag Care Pharm 2006;12:466-71.

5. Schectman JM, Nadkarni MM, Voss JD. The association between diabetes metabolic control and drug adherence in an indigent population. Diabetes Care 2002;25:1015-21.

6. Krapek K, King K, Warren SS, George KG, Caputo DA, Mihelich K, et al. Medication adherence and associated hemoglobin A1C in type 2 diabetes. Ann Pharmacother 2004;38:1357-62.
7. Lee WC, Balu S, Cobden D, Joshi AV, Pashos CL. Prevalence and economic consequences of medication adherence in diabetes: $\mathrm{A}$ systematic literature review. Manag Care Interface 2006;19:31-41.

8. Sokol MC, McGuigan KA, Verbrugge RR, Epstein RS. Impact of medication adherence on hospitalization risk and healthcare cost. Med Care 2005;43:521-30.

9. World Health Organization, diabetes mellitus fact sheet, number 238, 2002. Available from: http://www.who.int/chp/knowledge/ publications/adherence_full_report.pdf [Last Accessed on 2012 Nov 10].

10. Wabe NT, Angamo MT, Hussein S. Medication adherence in diabetes mellitus and self management practices among type-2 diabetics in Ethiopia. N Am J Med Sci 2011;3:418-23.

11. Grant RW, Devita NG, Singer DE, Meigs JB. Polypharmacy and medication adherence in patients with type 2 diabetes. Diabetes Care 2003;26:1408-12.

12. Santhosh YL, Naveen MR. Medication adherence behavior in chronic diseases like asthma and diabetes mellitus. Int J Pharm Pharm Sci 2011;3:238-40.

13. Isomaa B, Almgren $P$, Tuomi T, Forsén B, Lahti K, Nissén M, et al. Cardiovascular morbidity and mortality associated with the metabolic syndrome. Diabetes Care 2001;24:683-9.

14. Haynes RB, McKibbon KA, Kanani R. Systematic review of randomized trials of interventions to assist patients to follow prescriptions for medications. Lancet 1996;348:383-6.

15. Graves MM, Roberts MC, Rapoff M, Boyer A. The efficacy of adherence interventions for chronically ill children: A meta-analytic review. J Pediatr Psychol 2010;35:368-82.

16. Rolnick S, Pawloski P, Bruzek R, Hedblom B, Asche S, Fustgaard M, et al. PS2-32: Barriers and facilitators for medication adherence. Clin Med Res 2011;9:157.

17. Vervloet M, Linn AJ, van Weert JC, de Bakker DH, Bouvy ML, van Dijk $L$. The effectiveness of interventions using electronic reminders to improve adherence to chronic medication: A systematic review of the literature. J Am Med Inform Assoc 2012;19:696-704.

18. Dayer L, Heldenbrand S, Anderson P, Gubbins PO, Martin BC. Smartphone medication adherence apps. J Am Pharm Assoc 2013;53:172-81.

How to cite this article: Medi RK, Mateti UV, Kanduri KR, Konda SS. Medication adherence and determinants of non-adherence among south Indian diabetes patients. J Soc Health Diabetes 2015;3:48-51.

Source of Support: Nil. Conflict of Interest: None declared. 